\title{
Agronomic characterization of forage grain crops
}

\author{
Eranildo Brasil da Silva', Maria Socorro de Souza Carneiro', Flávia Louzeiro de Aguiar Santiago2*, \\ Ricardo Loiola Edvan², Leilson Rocha Bezerra², Elzânia Sales Pereira'
}

\author{
'Universidade Federal do Ceará, Fortaleza, CE, Brasil \\ ${ }^{2}$ Universidade Federal do Piaú, Bom Jesus, Pl, Brasil \\ *Corresponding author, e-mail: flavia-lo-uzeiro@hotmail.com
}

\begin{abstract}
The aim of this research was to accomplish agronomic and chemical composition of four forage species under the Brazilian semiarid conditions. The experimental design was a randomized block, in which the treatments consisted of forage crops: corn cv. BRS 205, millet cv. BRS 1501, sorghum $\mathrm{cv}$. IPA 467-4-2 and sunflower cv. Catissol 01, with four repetitions. It was measured plant height $\left(\mathrm{m}^{2}\right)$, number of plants, leaf/stem ratio, dry matter percentage, total dry matter and the chemical composition of different forage species. The sorghum showed a greater growth, reaching a height of $270.90 \mathrm{~cm}$. For the leaf $/ \mathrm{stem}$ ratio, the best results were observed by corn, followed by sunflower. In the chemical composition, the sunflower stood out compared to the other materials for crude protein, lipids and mineral contents. Sorghum present greater growth and mass production of straw for the Brazilian semi-arid conditions. The studied species have appropriate chemical composition characteristics, except for sunflower that has high ether extract contents.
\end{abstract}

Keywords: Helianthus annuus L.; Pennisetum glaucum L.; chemical composition; Sorghum bicolor L. Moench; Zea mays L.

\section{Caracterização agronômica de forrageiras produtoras de grãos}

\section{Resumo}

Objetivou-se neste trabalho realizar comparações agronômicas e químico-bromatológica nas condições do Semiárido brasileiro, entre quatro espécies forrageiras. O delineamento experimental foi em blocos ao acaso, no qual os tratamentos constaram das espécies forrageiras: milho cv. BRS 205, milheto cV. BRS 1501, sorgo cv. IPA 467-4-2 e girassol cv. CATISSOL 01, com quatro repetições. Foi mensurada a altura da planta, número de plantas $\left(\mathrm{m}^{2}\right)$, relação folha/colmo, porcentagem de matéria seca, massa seca de forragem total e a composição químico-bromatológica das diferentes espécies forrageiras. A cultura do sorgo demonstrou maior crescimento, atingindo uma altura de $270,90 \mathrm{~cm}$. Na razão folha/colmo, o milho apresentou maior relação, seguido pelo girassol. Na composição química-bromatológica a cultura do girassol se destacou em relação aos demais materiais quanto ao teor de proteína bruta, extrato etéreo e materiais minerais. O sorgo apresenta maior crescimento e produção de massa de forragem nas condições do semiárido brasileiro. As espécies estudadas apresentam características de composição químico-bromatológica adequadas, exceto o girassol que possui altos teores de extrato etéreo.

Palavras-chave: Helianthus annuus L.; Pennisetum glaucum L.; químico-bromatologica; Sorghum bicolor L. Moench; Zea mays L. 


\section{Introduction}

The irregularity of rainfall in semiarid regions provides native pastures with low carrying capacity and lead to a difficult establishment of cultivated pastures. These factors make the cattleman activity increasingly costly; however, some technologies are able to contribute to an increase in the livestock in the Northeast of Brazil.

The use of forage grain producers cultivars that are adapted to the conditions of dry season and high insolation combined with conservation methods has shown that it is possible to have good productivity in terms of dry matter forage even with these limitations. According to Pinho et al. (2013), to reduce the seasonality impacts on forage production is necessary to use the fodder surplus from the rainy season during the lean period.

Thus, Borges et al. (2012) reported that the forage conservation for subsequent use in the dry season, also known as silage, is one of the most versatile and viable options to meet the feed and nutritional deficit of herds during dry periods of the year.

In this context, the objective of this study was to compare agronomical and chemical characteristics of four forage species in the conditions of the Brazilian semiarid region.

\section{Material and methods}

The experiment was performed in the Anima Science Department of the Federal University of Ceara, Fortaleza, CE, Brazil. The city of Fortaleza is located in the Coastal Zone, $21 \mathrm{~m}$ above sea level, 3०43'02" south Latitude and 38³2'35 " west Longitude. According to Köppen classification, the climate is Aw, rainy tropical, with rainfall in the summer, with $800 \mathrm{~mm}$ of average.

The experiment was conducted from March to October, 2012. During the experiment, the accumulated rainfall was $1059.2 \mathrm{~mm}$ and the monthly average was $132.4 \mathrm{~mm}$, with an average temperature of $26.9^{\circ} \mathrm{C}$, reaching $31.2^{\circ} \mathrm{C}$.

Soil samples were collected in the experimental area at a depth of $0.2 \mathrm{~m}$, for examination in the laboratory, which had the following chemical properties: $\mathrm{pH}=5.7 ; \mathrm{P}=38$ $\mathrm{mg} \mathrm{dm}^{-3} ; \mathrm{K}=17 \mathrm{mg} \mathrm{dm}^{-3} ; \mathrm{Ca}=1 \mathrm{cmol} \mathrm{dm}^{-3} ; \mathrm{Mg}$
$=1 \mathrm{mg} \mathrm{dm}^{-3} ; \mathrm{Al}=0 \mathrm{mg} \mathrm{dm}^{-3} ; \mathrm{In}=6 \mathrm{mg} \mathrm{dm}^{-3}$. The experimental design was a randomized block with four repetitions, in an area of $325 \mathrm{~m}^{2}$ that was divided into 16 plots with $10 \mathrm{~m}^{2}$ each, with spacing blocks and plots with $1 \mathrm{~m}$ wide.

The treatments included four forage: corn (Zea mays L.) cV. BRS 205, millet (Pennisetum glaucum L.) cV. BRS 1501, sorghum (Sorghum bicolor L. Moench) cV. IPA 467-4-2 and sunflower (Helianthus annuUs L.) CV. CATISSOL 01. According to soil analysis, the recommendation of base fertilization was carried out, corresponding to the amount of $122 \mathrm{~g}$ of urea, $194 \mathrm{~g}$ of superphosphate and $37 \mathrm{~g}$ of potassium chloride per plot.

Sowing was held on March 13, 2012 in line with depths of $3 \mathrm{~cm}$ and 12 seeds per meter for the species and the number of lines was determined according to the morphological characteristics of each culture.

The analysis of productive characteristics of each species were determined according to grain maturity of the forage species. Plant height $(\mathrm{PH})$, number of plants per square meter $\left(\mathrm{NP} / \mathrm{m}^{2}\right)$, leaf/stem ratio (L/S) and forage dry mass (DMF) were evaluated. The collected material was weighed in the field, obtaining the total green mass, when a sample was picked up for the dry mass determination.

The plant material of two plants from each block was separated according to the parts: leaf, stem, dead material and inflorescence. Then, samples of $300 \mathrm{~g}$ were pre-dried in forced air ovens at $55^{\circ} \mathrm{C}$ for 72 hours and ground in a Willey mill equipped with a $1.0 \mathrm{~mm}$ sieve to determine dry matter (DM) (Method 967.03 - AOAC, 1990), minerals (Method 942.05 - AOAC, 1990), crude protein (CP) (Method 981.10 - AOAC, 1990), and ether extract (EE) (Method 920.29 - AOAC, 1990). To determine the NDF and ADF contents, the methodology of Van Soest et al. (1991) was used with the modifications that were proposed by the Ankon device manual (Ankon Technology Corporation, Macedon, New York, US).

The results were statistically analyzed by means of Student test at $5 \%$ of significance level, using the SISVAR software version 5.3, developed by the Federal University of Lavras (Ferreira, 2011). 


\section{Results and Discussion}

For the variables number of plants, plant height, leaf/stem ratio and dry matter the difference $(p<0.05)$ between the species were studied (Table 1).

The plants of the corn and sunflower species showed the same behavior for $N^{\circ} \mathrm{PL}\left(\mathrm{m}^{2}\right)$, with lower average than those found in sorghum and millet. These results can be related to the higher physiological demand of the crops. The second cut millet presented higher $\mathrm{N}^{\circ} \mathrm{PL}\left(\mathrm{m}^{2}\right)$, possibly because it was submitted to a water stress at the end of the rainy season, which may have stimulated the sprouting of new plants as a species survival mechanism.

Table 1. Mean values and coefficient of variation (CV\%) of crops for number of plants ( $\mathrm{N}^{\circ} \mathrm{PL}$ ), plant height $(\mathrm{PH})$, leaf/stem ratio (L/S), total forage dry matter (DMFT) and percentage of dry matter (DM\%), in different forages.

\begin{tabular}{lccccc}
\hline Forages & $\mathrm{N}^{\circ} \mathrm{PL}\left(\mathrm{m}^{2}\right)$ & $\mathrm{PH}(\mathrm{cm})$ & $\mathrm{L} / \mathrm{S}$ & DMFT $\left(\mathrm{h} \mathrm{ha}^{-1}\right)$ & $\mathrm{DM}(\%)$ \\
\hline Sunflower & $8.31 \mathrm{~b}$ & $146.95 \mathrm{bc}$ & $0.45 \mathrm{a}$ & $12.70 \mathrm{~b}$ & $19.55 \mathrm{~d}$ \\
Millet cut 1 & $15.62 \mathrm{ab}$ & $167.85 \mathrm{~b}$ & $0.22 \mathrm{cb}$ & $13.38 \mathrm{~b}$ & $25.68 \mathrm{~cd}$ \\
Millet cut 2 & $17.16 \mathrm{a}$ & $73.47 \mathrm{~d}$ & $0.20 \mathrm{cb}$ & $14.78 \mathrm{~b}$ & $34.04 \mathrm{ab}$ \\
Sorghum cut 1 & $14.25 \mathrm{ab}$ & $270.90 \mathrm{a}$ & $0.18 \mathrm{c}$ & $26.12 \mathrm{~b}$ & $29.87 \mathrm{bc}$ \\
Sorghum cut 2 & $12.37 \mathrm{ab}$ & $118.30 \mathrm{c}$ & $0.23 \mathrm{cb}$ & $23.59 \mathrm{~b}$ & $37.25 \mathrm{a}$ \\
Corn & $9.19 \mathrm{~b}$ & $127.20 \mathrm{c}$ & $0.59 \mathrm{a}$ & $21.37 \mathrm{~b}$ & $32.78 \mathrm{ab}$ \\
Millet annual & - & - & - & $28.16 \mathrm{~b}$ & - \\
Sorghum annual & - & - & - & $49.72 \mathrm{a}$ & - \\
\hline \multicolumn{4}{c}{$\mathrm{CV}(\%)$} \\
\hline Means followed by different letters in the column differ by Student's test (P<0.05).
\end{tabular}

The plant height is important because it is usually related to the production; however, this experiment could not find this result (Table 1). According to the Agronomic Institute of Pernambuco (2000), sorghum cV culture. IPA 467-4-2 growth has genetic characteristics of 250 to $350 \mathrm{~cm}$, and under conditions of this test, the first cut of the plants reached an average height of $270.90 \mathrm{~cm}$, but corresponding to a the good performance of the crop in the field.

Sorghum plants of the first cut showed higher growth when compared to the second cut plants (118.30 cm). Botelho et al. (2010) evaluated four sorghum cultivars, wherein the plant height reached $177-235 \mathrm{~cm}$, which agrees to the values found in this experiment. With the average obtained in the sorghum first and second cuts, it was possible to prove the stress caused to the development of this crop during the late rainy season.

For millet, the average plant height found in this experiment corroborate to the results obtained by Pinho et al. (2013), where the plants showed more significant results in the second cut. Possibly, this difference in results were related to the plant stress in the second cut of this experiment, during the dry season.

Corn has a greater L/S amount ratio, followed by sunflower and the corresponding values were; 0.59 and 0.45 respectively. The greater L/S ratio, indicates a greater participation of leaves in the fodder mass production, which ensures a higher quality of the produced forage. In general, the species showed lower L/S ratio, due to their morphological characteristics, as they have wet stem, besides the fact that these species possess high grain production, which favors the better composition of the plant, even with this low ratio.

For total forage dry matter (DMFT) the sorghum presented greater production when compared to other studied species, obtaining annual value of $49.72 \mathrm{tha}^{-1}$. This result is related to the fact that sorghum presented two cuts and have maintained their development during the drought stress period, which occurred at the end of the rainy season. Regarding the DMFT results, the millet crop were different from sorghum, since two cuts for the crop do not lead to an adequate development, due to the water stress during the second period of the harvest. Probably the sorghum crop has a more developed root system, allowing greater water absorption into the deeper layers, which confirms the statement of Botelho et al. (2010).

For the dry matter (DM\%) percentage, the higher averages were obtained by corn (32.78\%), second cut sorghum (37.25\%), millet 
(34.04\%) and first cut sorghum, that despite having improved the growth rate, reached a height of $270.90 \mathrm{~cm}$ and presented a dry matter percentage similar to the first cut millet, but lower in relation to the dry matter production of the second cut, for both cultures. The DM\% results of this research forsorghum, approaches the values founded by Skoniesk et al. (2010) which achieved a DM\% from 15 to $35 \%$.

Differences $(p<0.05)$ between the chemical composition variables of forage plants were observed and are shown in Table 2.

Table 2. Means values and coefficient of variation (CV\%) of crude protein (CP), ether extract (E), ash, neutral detergent fiber (NDF) and acid detergent fiber (ADF) of the chemical composition of different forage species.

\begin{tabular}{lccccc}
\hline Species & CP \% & EE \% & Ash\% & NDF\% & ADF \% \\
\hline Sunflower & $12.50 \mathrm{a}$ & $16.13 \mathrm{a}$ & $11.78 \mathrm{a}$ & $40.16 \mathrm{~b}$ & $31.27 \mathrm{c}$ \\
Millet cut 1 & $9.06 \mathrm{~b}$ & $2.19 \mathrm{~b}$ & $11.90 \mathrm{a}$ & $65.10 \mathrm{a}$ & $37.2 \mathrm{ab}$ \\
Sorghum & $5.57 \mathrm{c}$ & $1.74 \mathrm{~b}$ & $4.63 \mathrm{c}$ & $63.73 \mathrm{a}$ & $38.14 \mathrm{a}$ \\
Cut 1 & $8.31 \mathrm{~b}$ & $2.09 \mathrm{~b}$ & $8.45 \mathrm{~b}$ & $58.24 \mathrm{a}$ & $32.50 \mathrm{bc}$ \\
Corn & 11.16 & 10.47 & 12.38 & 6.24 & 6.82 \\
\hline CV (\%) & \multicolumn{4}{c}{} &
\end{tabular}

These variables are important for the assessment of the crop potential in forage production, making easier to understand the obtained results.

In this experiment, it was observed that the sunflower crop stood out over the other species regarding the CP\% content, due to the high amount of seeds in each chapter, which lead to the highlight of the crop in silage production, with a greater CP\%. The sunflower forage CV CATISSOL 01 showed CP\% equivalent to $12.50 \%$, followed by millet(9.06\%), corn $(8.31 \%)$ and sorghum (5.57\%).

According Van Soest (1994) the minimum value for $\mathrm{CP}$ in sorghum should be $7 \%$, which is considered ideal for the proper functioning of the rumen. However, in literature is possible to observe superior results when compared to those observed in this experiment, for sorghum.. Neumann et al. (2001) found values of $10.9 \%$ to $11.6 \%$ between four hybrids fertilized with 150 $\mathrm{kg} \mathrm{ha}^{-1}$ of urea; Rodrigues et al. (2002) observed levels of $13.0 \%$ of CP to Agroceres hybrid. This fact is related to the nitrogen fertilization, that can affect the crop CP content.

The value of the ether extract (EE) differed significantly only for sunflower, with an average of $16.13 \%$. Mello et al. (2004) reports that sunflower silage contains ether extract about $17.4 \%$, since the corn silage levels are lower (4.2\%) but considered high for silages, which typically has $3.6 \%$ of EE.

Ash contents in the forage plants differed statistically, demonstrating the greater average for sunflower and millet plants, with 11.78 and $11.90 \%$, respectively, and the lowest contents was observed for sorghum, with $4.63 \%$, and the corn crop presented intermediate values (8.45\%). The NDF content was lower than the ADF contents observed for sunflower, with 40.16 and $31.27 \%$, respectively. This may be justified by the fact that the sunflower crop has greater lignified fiber content, which may end up hindering the silage digestibility.

\section{Conclusions}

Sorghum present greater growth and forage mass production in the Brazilian semi-arid conditions. All species presented appropriate chemical composition, except for sunflower, which presented higher ether extract contents.

\section{References}

AOAC. 1990. Association Official Analytical Chemist (Official Methods of Analysis). 15th ed. AOAC, Washington, DC, USA.

Borges, G.A., Aguiar, A.C.R., Madureira, K.L., Santos, L.V., Santos, R.S., Moreira, S.J.M. 2012. Nutritional evaluation of silages from sunflower hybrids. Revista Agropecuária Científica no SemiÁrido 8: 01-06.

Botelho, P.R.F., Pires, D.A.A., Sales, E.C.J., Rocha Júnior, V.R., Jayme, D.G., Reis, S.T. 2010. Evaluation of genotypes of sorghum in first cutting and regrowth for silage production. Revista Brasileira de Milho e Sorgo 9: 287-297.

Ferreira, D.F. 2011 . Sisvar: a computer statistical analysis system. Ciência e Agrotecnologia 35: 1039-1042. 
Instituto Agronômico de Pernambuco - IPA. 2000. Sorgo sacarino de elevada produção de biomassa para corte e silagem cv. IPA 467-4-2.

Mello, R., Nörnberg, J.L., Rocha, M.G. 2004. Productive and qualitative performance of corn, sorghum and sunflower hybrids for ensiling. Revista Brasileira Agrociência 10: 87-95.

Neumann, M., Restle, J., Alves Filho, D.C., Brondani, I.L., Bernardes, R.A.C., Souza, A.N.M., Kuss, F. 2001. Feedlot performance of steers fed with silages of sorghum (Sorghum bicolor, L. Moench) or corn (Zea mays, L.) hybrids. Revista Sociedade Brasileira de Zootecnia 30: 2099-2109.

Pinho, R.M.A., Santos, E.M., Rodrigues, J.A.S., Macedo, C.H.O., Campos, F.S., Ramos, J.P.F., Bezerra, H.F.C., Perazzo, A.F. 2013. Evaluation of genotypes of pearl millet for silage in semiarid. Revista Brasileira de Saúde e Produção Animal 14: 426-436.

Rodrigues, P.H.M., Senatore, A.L., Andrade, S.J.T., Ruzant, J.M., Lucci, C.S., Lima, F.R. 2002. Effects of microbial inoculants on chemical composition and fermentation characteristics of sorghum silage. Revista Brasileira Zootecnia 31: 2373-2379.

Skonieski, F.R., Nornberg, J.L., Azevedo, E.B., David, D.B., Kessler, J.D., Menegaz, A.L. 2010. Production, fermentation and nutritional characteristics of forage and double purpose sorghum silages. Acta Scientiarum. Animal Science 32: 27-32.

Van Soest, P.J., Robertson, J.B., Lewis, B.A. 1991. Methods for dietary fiber, neutral detergent fiber and non-starch polysaccharides in relation to animal nutrition. Journal of Dairy Science 74: 3583-3597.

Van soest, P.J. 1994. Nutricional ecology of the ruminant. Ithaca: Comstok Publishig Associations, $476 \mathrm{p}$. 